\title{
SEX-TYPING OF BLUE-CROWNED LAUGHINGTHRUSH (GARRLUAX COURTOISI) USING CHD1-BASED POLYMERASE CHAIN REACTION
}

\author{
HUANG, J. ${ }^{1,2 \#}-$ MAO, H. ${ }^{3 \#}-\mathrm{XU}, \mathrm{H} .{ }^{1}-$ TANG, J. ${ }^{1}-$ OUYANG, J. ${ }^{1}-\mathrm{WU}, \mathrm{Z}^{4}-\mathrm{LIU}, \mathrm{D} .{ }^{4 *}-\mathrm{YAN}, \mathrm{X} .{ }^{1,{ }^{*}}$ \\ ${ }^{1}$ College of Life Sciences, Jiangxi Science and Technology Normal University, Nanchang, \\ Jiangxi Province, China \\ ${ }^{2}$ Jiangxi Key Laboratory of Bioprocess Engineering, Jiangxi Science and Technology Normal \\ University, Nanchang, Jiangxi Province, China \\ ${ }^{3}$ College of Animal Sciences, Jiangxi Agricultural University, Nanchang, Jiangxi Province, \\ China \\ ${ }^{4}$ Nanchang Zoo, Nanchang, Jiangxi Province, China \\ *Corresponding author \\ e-mail: liudaoqiang@foxmail.com,xuemingyan@hotmail.com \\ ${ }^{\#}$ These authors contributed equally to this work \\ (Received $31^{\text {st }}$ May 2018; accepted $2^{\text {nd }}$ Aug 2018)
}

\begin{abstract}
Blue-crowned laughingthrush (Garrluax courtoisi), an endemic species in China, is a critically endangered and sexually monomorphic bird. It is difficult to identify the gender of this species through the observation of its external morphology. To solve this problem, we herein established a CHDI-based PCR method for sex-typing of Garrluax courtoisi. We first collected blood samples from six Bluecrowned laughingthrush raised in Nanchang Zoo, and then extracted high-quality genomic DNA from blood clots using an optimized phenol/chloroform method. We designed a degenerate primer pair to amplify fragments of the CHDI gene, resulting an amplicon of $700 \mathrm{bp}$ for males and an extra PCR product of $600 \mathrm{bp}$ for females. We also performed extensive behavioral observations of these six birds and the obtained data allowed us to deduce the sexes of these birds. The sex-typing results are generally consistent with the behavior-deduced results. This study sheds light on the sex determination of other endangered birds, and also paves a road to further test the reproduction mechanism, taxonomic classification and population relationships of Garrluax courtoisi.
\end{abstract}

Keywords: blue-crowned laughingthrush, sex identification, CHD1, endangered species

\section{Introduction}

Blue-crowned laughingthrush (Garrulax courtoisi, Fig. 1) is currently classified as a critically endangered bird by BirdLife International (2017). The only known wild population of approximately 300 birds currently lives in Wuyuan County, Jiangxi Provence, China (He et al., 2017). Its emergence and re-emergence after a long period of disappearance is really a mystery to people. Also its status in taxonomy has changed several times. Thus it is regarded as a legend in birds.

Currently a total of slightly more than 200 birds are kept captive in several zoos located in Asia, Europe, and North America (Liu et al., 2017). We started a captive breeding program for this species in 2010 in the Nanchang Zoo at Nanchang City, Jiangxi Province of China, and joined the Global Species Management Plan (GSMP) (WAZA, n. d.) in 2012. One of the major obstacles we have been facing is the sextyping of these sexually monomorphic birds, as the birds do not have any external 
genitalia. Traditional sexing methods involve physical examination of the cloacae or the use of a laparoscope, both are invasive to such small birds and may cause anaphylaxis or death during the procedures. As sexing is inevitable as a management requirement, we decided to evaluate the feasibility of using a relatively safer molecular sex-typing method.

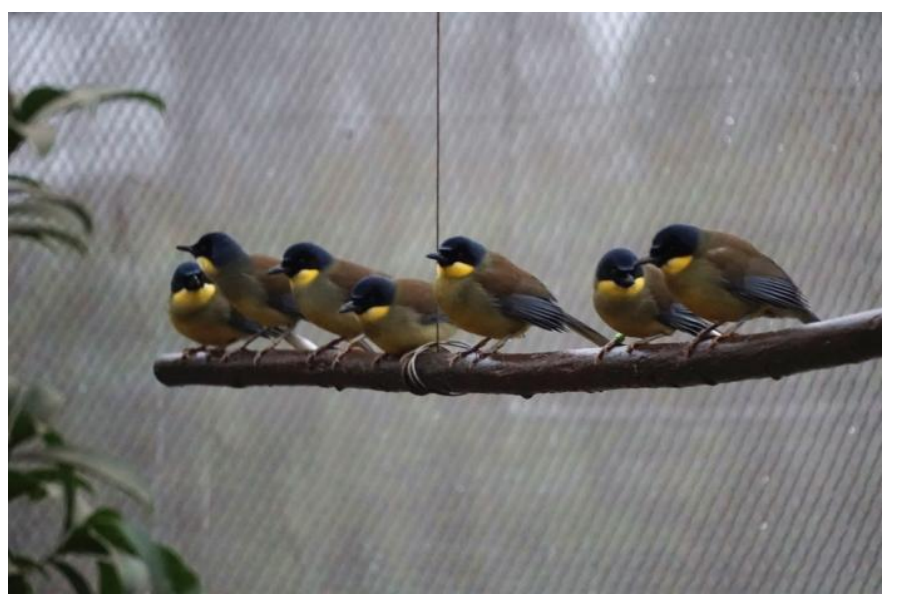

Figure 1. The blue-crowned laughingthrush in Nanchang Zoo

There have been several useful molecular sex-typing protocols established for birds over the past decades (Griffiths et al., 1998; Lessells and Mateman, 1996), among which the amplification of an intron of the $C H D 1$ gene has been successfully used for a range of avian species (Fridolfsson and Ellegren, 1999, 2000). The CHD1 gene is located on sex chromosomes and is highly conserved in non-ratite birds. Chromosomes $\mathrm{W}$ and $\mathrm{Z}$ carry nearly identical exons but different sizes of introns of this gene. The $C H D 1$-specific primer pair can be used to generate different amplicons representing $Z W$ (female) and $W W$ (male) individuals. In this study, we sought to test whether this method can be used for sex-typing of Garrluax courtoisi, and discussed its correlation with behavioral characteristics of the birds.

\section{Materials and methods}

\section{Animals}

Seven Garrluax courtoisi birds (numbered 1-7) were kept captives in the Nanchang Zoo, Nanchang City in Jiangxi Provence. Color-coded foot bands were placed to facilitate visual identification of the birds from distance. A total of $40 \mu \mathrm{l}$ blood was drawn from the brachial vein and dropped into tubes containing 75\% ethanol and saved in $-20{ }^{\circ} \mathrm{C}$ until used for DNA isolation. We were unable to capture bird \#5, thus blood sample for this bird was not collected.

\section{Behavioral observations}

Extensive behavioral observations of these birds were documented from 2014 to 2016, especially during the breeding seasons. These birds are small in size and move swiftly. It was still quite difficult to trace every individual bird, especially when visibility was low, even though they wore color-coded foot-bands. In order to establish 
correlations between behavioral characteristics and molecular sexing results, we put our efforts to the following observations: 1) the presence of prelaying behaviors, including preening, elaborate display, or chasing of females; 2) documentation of nesting and egglaying in varying grouping strategies to identify the reproducing females; and 3) observation of brooding behavior to identify the egg-laying female, and, ideally, the pairing male. It has been known that the breeding bird during the night is predominately the egg-laying female (Reul-Schneider and Schneider, 2006).

\section{Genomic DNA isolation}

Genomic DNA was isolated from blood clots using a commercial genomic DNA isolation kit CW2298 (Kang Wei, China), a standard phenol/chloroform method and an optimized phenol/chloroform method by testing different volumes of lysis buffer, concentrations of Proteinase $\mathrm{K}$ and digestion time (Table 1). DNA concentration and quality were measured using a NanoDrop 2000 spectrophotometer (Thermo Fisher Scientific, USA) and $0.8 \%$ agarose gel electrophoresis.

Table 1. Optimization parameters of DNA extraction

\begin{tabular}{c|c|c}
\hline Lysis buffer (ul) & Digestion time (h) & Proteinase K (ul) \\
\hline 400 & 2 & 2 \\
450 & 4 & 4 \\
500 & 6 & 6 \\
500 & 8 & 8 \\
500 & 10 & 10 \\
500 & 15 & 15 \\
\hline
\end{tabular}

\section{PCR sex-typing}

Primers 2550F/2718R (Forward: 5'-GTTACTGATTCGTCTACGAGA-3'; Reverse: 5'-ATTGAAAT GATCCAGTGCTTG-3') were designed based on a conservative intronic region within the CHD gene (Fridolfsson and Ellegren, 2000). PCR was conducted in $25 \mu \mathrm{l}$ reactions containing $40 \mathrm{ng}$ genomic DNA, $2.5 \mu \mathrm{M} 10 \times$ buffer, $25 \mathrm{mM} \mathrm{MgCl} 2,2.5 \mathrm{mM}$ dNTP, $0.2 \mu \mathrm{M}$ each of primers and 2.5 units Taq polymerase (Tiangen, China). The PCR reaction profile was as follows: $94{ }^{\circ} \mathrm{C}$ for $5 \mathrm{~min}, 29$ cycles of $94{ }^{\circ} \mathrm{C}$ for $30 \mathrm{~s}, 65^{\circ} \mathrm{C}$ (decreasing $0.5{ }^{\circ} \mathrm{C}$ every cycle) for $20 \mathrm{~s}, 72{ }^{\circ} \mathrm{C}$ for $40 \mathrm{~s}$; then followed by 14 cycles of $94{ }^{\circ} \mathrm{C}$ for $30 \mathrm{~s}, 50{ }^{\circ} \mathrm{C}$ for $20 \mathrm{~s}, 72{ }^{\circ} \mathrm{C}$ for $40 \mathrm{~s}$; reaction was ended after a final extension of $10 \mathrm{~min}$ at $72{ }^{\circ} \mathrm{C}$. Eight $\mu \mathrm{l}$ of the PCR product was loaded to a $2.5 \%$ agarose gel (containing ethidium bromide) for electrophoresis. A 50bp ladder (Tiangen, China) was used to indicate the sizes of the PCR products. DNA bands were visualized under UV light and pictures taken. PCR products were purified from agarose gel using a gel purification kit (Qiagen, Germany) and sent for sequencing using primers $2550 \mathrm{~F}$ and $2718 \mathrm{R}$ (BGI, China).

\section{Results}

\section{Behavioral observations indicate the gender of Garrluax courtoisi birds}

From 2014 to 2016, eight blue-crowned laughingthrushes including seven birds tested in this study were separated into different groups (Table 2). These birds were 
painstakingly inspected for nest building, egg laying and hatching. Both male and female birds have existed in this flock, as one brood of chicks was hatched each year in 2014 through 2016 (Table 2). One extra nest was built, into which no egg was laid, both in year 2014 and year 2016. There had been no obvious courtship displays or aggressiveness observed during the last three mating seasons. However, flocked chasing was frequently seen among blue-crowned laughingthrushes, similar to that seen in Darwin's finches on the Galápagos Islands. It has been believed that chasing of the female by the male promotes sexual synchronization between the two sexes, leading to successful copulation and insemination. Chasing of bird \#2, mostly led by bird \#6, has been frequently observed during the mating seasons in years 2015 and 2016, although pairing could not be confirmed. Bird \#4 also showed chasing activity to a lesser extent in these two mating seasons. In addition, the birds were divided into two groups during the breeding seasons in year 2014 and year 2016, and the broody group included bird \#2 in both years (Table 2). This suggests that bird \#2 was the breeding female in these three years while bird \#6 was the dominant male in the same period.

Table 2. Reproduction record of blue-crowned laughingthrush (Garrluax courtoisi) in Nanchang Zoo from year 2014 through 2016

\begin{tabular}{c|c|c|c|c|c}
\hline Year & Groups & Birds in group & Nests built & Eggs laid & Chicks hatched \\
\hline \multirow{2}{*}{2014} & A & $\# 2, \# 5, \# 8^{*}$ & Yes & Yes & Yes \\
& B & $\# 1, \# 3, \# 4, \# 6, \# 7$ & Yes & No & No \\
\hline \multirow{2}{*}{2015} & C & $\# 1 \sim 7$ (no division) & Yes & Yes & Yes \\
\hline \multirow{2}{*}{2016} & D & $\# 1, \# 2, \# 4, \# 6$, & Yes & Yes & Yes \\
& E & $\# 3, \# 5, \# 7$ & Yes & No & No \\
\hline
\end{tabular}

*Bird \#8 died for unknown reason at the end of 2014; this bird was male by autopsy

Both male and female blue-crowned laughingthrushes can be broody (Liu et al., 2016), but it is not clear how they cooperate or what specific roles they take. In this study, as the birds are loosely confined in a large wire mesh aviary, it is not clear whether there had been indeed a broody male. Previous captive breeding of this avian species suggests that the females are usually the brooding birds at night [8]. In the breeding season in year 2014, there was an attack by a snake (Dinodon rufozonatum) on the hatching nest, and the brooding female bird (bird \#2) was thought to be the last to abandon the nest. Birds have weak visions at night, but are sensitive to vibrations of the tree branches and hence the approaching snake. In addition, during the breeding seasons in year 2015 and year 2016, we took daily close-up checks of the hatching nest, and bird \#2 was nearly always perching nearby. This further suggests that bird \#2 was the only egg-laying female bird in these two years.

\section{An optimized method for isolation of genomic DNA of Garrluax courtoisi birds}

In this study, a commercial kit was first used to isolate genomic DNA of Garrluax courtoisi birds. However, the isolated DNA was of poor quality as the electrophoresis bands showed uneven brightness and a severe pollution of protein residue (Fig. 2). A standard phenol/chloroform method was then explored for DNA isolation, also resulting in poor-quality DNA. To solve this problem, we optimized this phenol /chloroform method by testing three parameters including the volume of lysis buffer, the concentration of Proteinase $\mathrm{K}$ and the digestion time. Finally, $500 \mu \mathrm{l}$ lysis buffer, $10 \mu \mathrm{l}$ 
Proteinase $\mathrm{K}$ and a digestion time of 8 hours were used in the extraction protocol, which allowed us to obtain high-quality genomic DNA from each blood clot (Fig. 2).

A

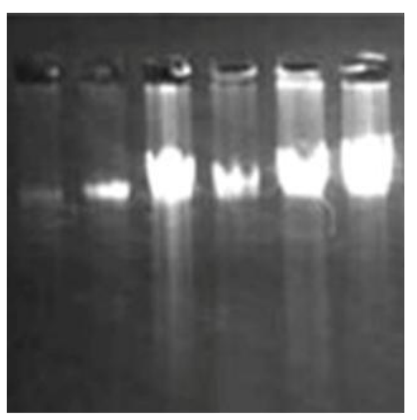

B

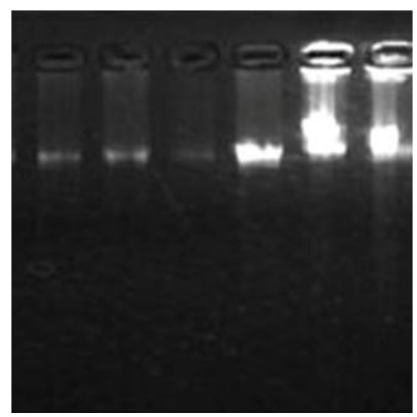

C

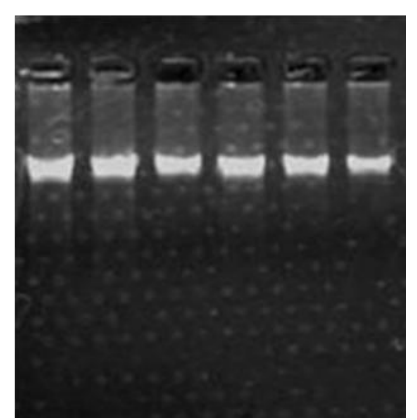

Figure 2. Electrophoresis patterns of genomic DNA isolated by three approaches. (A) A commercial kit. (B) A routine phenol chloroform method. (C) An optimized phenol chloroform method

\section{PCR sex typing}

The CHD1-based PCR generated one or two amplicons representing the two sexes (Fig. 3). Sequencing of the two PCR products confirmed that the 700 bp product was from $\mathrm{Z}$ chromosome, while the $600 \mathrm{bp}$ product was from the $\mathrm{W}$ chromosome. Thus, PCR with primers $2550 \mathrm{~F} / 2718 \mathrm{R}$ will generate only one band of $700 \mathrm{bp}$ for a male (ZZ) blue-crowned laughingthrush, and generate two bands (700 bp and $600 \mathrm{bp}$ ) for a female $(Z W)$. The two bands can be easily separated in a $2.5 \%$ agarose gel, and there was no amplicon other than the two alternative fragments. According to the PCR sex typing results, Birds \#2, 3 and 4 are female, and Birds\#1, 6 and 7 are males.

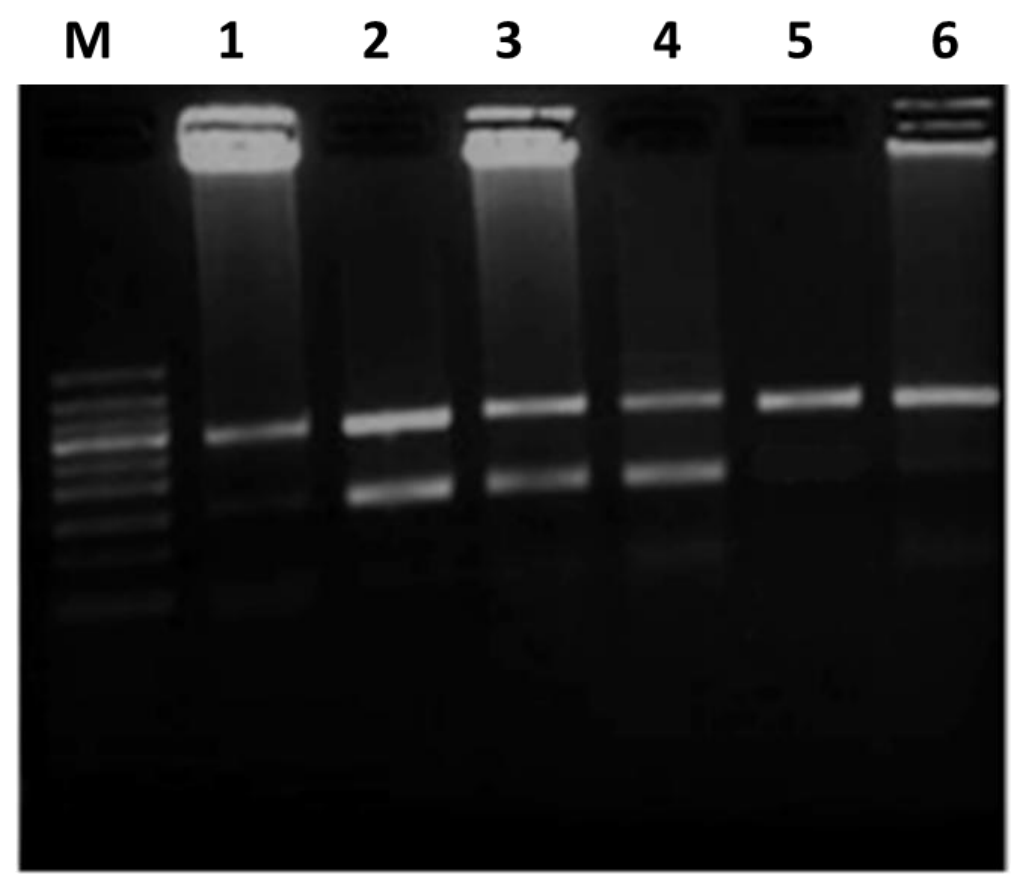

Figure 3. CHD1-based PCR sex-typing of blue-crowned laughingthrush (Garrulax courtoisi). A gel image of PCR products by primer pair 2550F/2718R. M, molecular marker; lines 1,5 and 6, $\mathrm{ZZ}$ (male) individuals; lines 2, 3 and 4, ZW (female) individuals 


\section{Discussion}

Blue-crowned laughingthrush is the critically endangered bird and the endemic species in China, it distributed in Simao, Yunnan and Wuyuan, Jiangxi in history. The existing wild blue-crowned laughingthrush is only in Wuyuan, and their population is more than 300. In 1980's and 1990's, blue-crowned laughingthrush were exported to Hong Kong, Europe and North America through wildlife trade. Presently, there are above 200 individuals in zoos or feeding units around the world including Nanchang Zoo. However, as a sexually monomorphic species, it is hard to determine their sex by body, voice or behaviour (Liu et al., 2016).

Bird \#2 had demonstrated apparent female behaviors and this is confirmed by PCR sex-typing; on the contrary, bird \#6 showed active chasing behavior and is indeed sextyped by PCR as male. Because there had been more than one nest built during two of the three breeding seasons from year 2014 to 2016, there were likely multiple female birds in the flock. PCR results revealed that birds \#2, \#3, and \#4 were females, while \#1, \#6 and \#7 were males. This represents a 1:1 male/female sex ratio in this small population. Birds \#3 and \#4 were both captured from the wild in year 2011 without knowledge of their ages or gender. The reasons for the absence of egg-laying from these two female birds could be complex. A sudden environmental change from the wild to the captive status may have affected their breeding behaviors, and the possibility cannot be excluded that they might have been carrying unnoticed diseases that affected reproduction; or they might simply have lost their reproductive ability due to aging. Our study suggests that behavioral characteristics can be used for gender identification with caution, as some of them are weak and sometimes misleading. For example, though bird \#4 showed chasing inclination during the two mating seasons in years 2015 and 2016, it was clearly demonstrated by PCR to be a female.

Itoh et al.(2001) have successfully identified the gender of flamingo using two pairs of primers in EE0.6 gene, which was then verified by the CHD1 gene-based method. The unambiguous and easily separable two PCR products from the CHD1 genes on the $\mathrm{Z}$ and the $\mathrm{W}$ chromosomes make this molecular sexing method a simple and reliable way for sex determination of blue-crowned laughingthrushes, avoiding the risk of severe physical injuries to the bird or death from traditional sex examination methods. It should be noted that DNA isolation from feathers should make this method even safer for the birds (Bello et al., 2001). As successful as in many other avian species, the accuracy of sex-typing brought by this non-invasive method is very helpful for the management of and research on populations of this critically endangered species.

\section{Conclusion}

In summary, blue-crowned laughingthrush is a critically endangered avian species. We used CDH1-specific primers for PCR sex-typing of this sexually monomorphic bird, and compared the PCR-typing results with the deduced gender of this bird on the basis of extensive behavioral observations. We believed that the method is reliable and non-invasive to the birds, thus it is an ideal tool for the management and study of this critically endangered species under captivity.

Acknowledgements. We thank Professor Jun Ren at the Jiangxi Agricultural University for his kind assistance in experimental design, data interpretation, and manuscript writing. This work was supported 
by these projects in China (2013-CXTD002, Co-Innovation Center for In Vitro Diagnostic Reagents and Devices of Jiangxi Province; National Natural Science Foundation of China (31460591;31401047;31660302;31760625); Natural Science Foundation of Jiangxi Province (20143ACB21006;20142BCB23028);Science and technology research project of Jiangxi Provincial Education Department(14571).

\section{REFERENCES}

[1] Bello, N., Francino, O., Sanchez, A. (2001): Isolation of genomic DNA from feathers. J. Vet. Diagn. Invest. 13(2): 162-164.

[2] BirdLife International (2017): Species factsheet: Garrulax courtoisi. http://www.birdlife.org. Accessed on 23/04/2017.

[3] Fridolfsson A. K., Ellegren, H. (1999): A simple and universal method for molecular sexing of nonratite birds. - J. Avian. Biol. 30: 116-121.

[4] Fridolfsson, A. K., Ellegren, H. (2000): Molecular evolution of the avian - CHD1 genes on the Z and W sex chromosomes. - Genetics 155(4): 1903-1912.

[5] Griffiths, R., Double, M. C., Orr, K., Dawson, R. J. G. (1998): A DNA test to sex most birds. - Mol. Ecol. 7(8): 1071-1075.

[6] He, F. Q., Lin, J. S., Wen, C., Lin, Z., Shi, Q. H., Huang, H. Q., Cheng, S. L., Xiao, H. (2017): Prelim of biology of the blue-crowned laughingthrush Garrulax courtoisi in Wuyuan of NE Jiangxi, SE China. - Chin. J. Zool. 52(1): 167-175.

[7] Itoh, Y., Suzuki, M., Ogawa, A. (2001): Identification of the sex of a wide range of Carinatae birds by PCR using primer sets selected from chicken EE0.6 and its related sequences. - J. Hered. 92: 315-321.

[8] Lessells, K., Mateman, C. (1996): Molecular sexing of birds. - Nature 383: 761-762.

[9] Liu, D. Q., Wu, Z. Y., Wang, X. H., Huang, H. L., Li, D. T. (2016): Cooperative breeding behaviour of captive blue-crowned laughingthrush (Garrulax courtoisi) . - Chin. J. Wildl. 37(3): 228-233.

[10] Liu, D. Q., Wang, X. H., Fu W.K., Lin J.S., Wu, Z. Y. (2017): Observation of BlueCrowned Laughingthrush Nestling Behaviors in Wuyuan, Hong Kong and Nanchang. Chin. J. Wildl. 38 (2):249-253.

[11] Reul-Schneider, M., Schneider, H. (2006): Some notes on our experiences of keeping and breeding the yellow-throated laughingthrush Garrulax galbanus courtoisi. - Avicul. Mag. 112(2): 53-56.

[12] WAZA (n. d.): Global Species Management Plan [EB/OL] http://www.waza.org/en/site/conservation/conservation-breeding-programmes/gsmp. Access date: 3/10/2012. 